\title{
DISASTERS FAST AND SLOW: THE TEMPORALITY OF HAZARDS IN ENVIRONMENTAL HISTORY
}

\author{
FIONA WILLIAMSON \\ School of Social Sciences, Singapore Management University \\ CHRIS COURTNEY \\ Department of History, Durham University
}

History ... functions in turn as an eyepiece, a microscope, or a telescope ... In changing scale, one does not see things as larger or smaller ... One sees different things ... There are different concatenations of configuration and causality.

Paul Ricoeur ${ }^{1}$

Popular representations of disasters tend to focus upon dramatic moments of chaos. They envision panicked communities desperately scrambling for safety as earthquakes reduce cities to rubble or lava turns villages to ashes. Yet disasters actually unfold on numerous temporal scales. Media reports tend to reduce disasters to discrete events, initiated on the shallow causal timescale of a meteorological fluctuation or seismic disruption. Social scientists, by contrast, have often sought to emphasise the processual nature of disasters-embedding causality in the deeper timescale of a community, in which risk and vulnerability build over months or years. ${ }^{2}$ Environmental historians elongate causality even further, describing how individual or recurrent disasters emerge from longue durée interactions between human and ecological systems. This approach underpinned many classic studies of the genre, including Donald Worster's description of how the dust storms of the Great Depression emerged from a context of unsustainable agricultural expansion onto the American prairies, and Peter Perdue's exploration of how chronic flooding in late imperial Hunan was the culmination of centuries of lakeshore reclamation. ${ }^{3}$ James Warren's article in this special issue builds upon this tradition, embedding individual famines that struck the Philippines within the longue durée history of economic and ecological exchange.

\footnotetext{
1 Paul Ricoeur, Memory, History Forgetting, trans. Kathleen Blamey and David Pellauer (Chicago and London: University of Chicago Press, 2006), 211.

2 See, for example, David Arnold, Famine, Social Crisis and Historical Change (New York: Basil Blackwell, 1988); Benjamin Wisner, Ian Davis, Piers Blaikie and Terry Cannon, At Risk: Natural Hazards, Peoples Vulnerability, and Disasters (London and New York: Routledge, 1994).

3 Donald Worster, Dust Bowl: The Southern Plains in the 1930s (New York: Oxford University Press, 1979); Peter C. Perdue, Exhausting the Earth: State and Peasant in Hunan, 1500-1850 (Cambridge, MA: Harvard University Press, 1987), doi.org/10.2307/j.ctt1 tg5gx4.
} 
Environmental historians have also sought to examine how trends in disaster occurrence are linked to specific time periods of earth's history. Most dramatically, perhaps, the periodic warming and cooling of the climate has inundated and desiccated the landscape, rendering regions that had once supported thriving human communities virtually uninhabitable. Whilst popular scholars, including Jared Diamond, have characterised such rapid transformations as disastrous civilisational collapses, recently James C. Scott has argued that such events may not be as calamitous as they appear; the collapse of an oppressive central state could benefit a majority of the population by improving their nutrition and freeing them from extractive labour. ${ }^{4}$ A disaster, it would seem, is a relative concept. It is hard to dispute, however, that rapid temperature changes have created periods of extreme difficulty for individual communities. Timothy Brook has described how periods of acute climatic distresswhich he calls 'sloughs'-blighted the lives of those living under the Yuan (12711368) and Ming empires (1368-1644), plaguing them with all manner of hazards, including severe cold weather and flooding. ${ }^{5}$ Other climate historians have sought to account for the temporal synchronicity of geographically dispersed disasters. While some have posited volcanic activity as a key common factor, the most influential studies of disaster synchronicity have been those examining the El Niño-Southern Oscillation (ENSO), which include the works of Mike Davies and Richard Grove. ${ }^{6}$ Several of the disasters analysed in this special issue were synchronised with this great climatic metronome, including the Chinese famines and Filipino typhoons examined by Mark Baker and James Warren respectively, and perhaps also the Australian droughts examined by Rebecca Jones. ${ }^{7}$

When hazards are viewed in generic terms, rather than as specific events or processes, the timescale can be extended even further back, to plot a deep history of disasters. The emergence of conflagrations as a hazard type is inextricable from the gradual process of urbanisation. ${ }^{8}$ Without cities there would be no city fires. Conversely, the decline of conflagrations in the modern world marked the epochal shift from a world of wood and earth to one of brick and concrete, as Chris Courtney explores in this issue. Likewise, numerous hazard types can trace their roots to the adoption

\footnotetext{
4 Jared M. Diamond, Collapse: How Societies Choose to Fail or Succeed (New York: Viking, 2005); Patricia Ann McAnany and Norman Yoffee, eds, Questioning Collapse: Human Resilience, Ecological Vulnerability, and the Aftermath of Empire (Cambridge and New York: Cambridge University Press, 2010); James C. Scott, Against the Grain: A Deep History of the Earliest States (New Haven, CT: Yale University Press, 2017).

5 Timothy Brook, The Troubled Empire: China in the Yuan and Ming Dynasties (Cambridge, MA and London: Belknap Press, 2010), doi.org/10.4159/9780674056206.

6 Mike Davies, Late Victorian Holocausts: El Niño Famines and the Making of the Third World (London and New York: Verso, 2000); Richard H. Grove, 'Global Impact of the 1789-93 El Niño', Nature 393, no. 6683 (1998): 318-19, doi.org/10.1038/30636; Richard Grove and George Adamson, El Niño in World History (London: Palgrave Macmillan, 2017).

7 Whilst not explicitly referring to ENSO in her account of late nineteenth- and early twentieth-century Australia, the series of droughts Jones discusses was likely related to the strong ENSO period (especially in the 1890 s and 1920s).

8 Stephen J. Pyne, Fire: A Brief History (Seattle, WA: University of Washington Press, 2001), 102-18.
} 
of sedentism, a process that fixed communities in the path of erupting volcanoes and raging rivers. The inexorable rise of agriculture created the precondition for famine by fostering dependency on weather-sensitive plants, whilst it incubated epidemics by encouraging zoonoses and overcrowding. ${ }^{9}$ Agriculture also reshaped the landscape of risk by contributing to the erosion of slopes and silting of rivers, a topic that Fiona Williamson explores in her article on the disaster of erosion in this issue. Many hazard types that might appear to be timeless consequences of life within a capricious environment, in fact belong to a very distinct temporal setting, being the products of settled agrarianism — a mode of life that is, in the deep history of our species, a rather recent innovation.

We need not stop there. We could chase the long tail of disaster causality back to the birth of volcanoes or the formation of tectonic plates. Yet infinite retrospection obscures as much as it reveals. The assumption that temporal proximity somehow diminishes the relative importance of a cause is quite erroneous, as every disaster is an agglomeration of both long- and short-term causes. Indeed, if we are to take the processual approach to disasters seriously then we must, as the geographers Michael Watts and Hans Bohle have insisted, think of vulnerability not solely as a pre-existing condition; new forms of vulnerability are created throughout the disaster process. ${ }^{10}$ Disasters do not stop being caused at a discrete point in time-'when the levee breaks', as Memphis Minnie famously put it. ${ }^{11}$ Rather, as Paul Ricoeur's epigram suggests, differing 'concatenations of configuration and causality' appear as we change our analytic lens. As much can be learned from a microscopic analysis of the immediate moment of disaster as can be gleaned from a telescopic view of longue durée socioenvironmental interactions. The trick is knowing when to change scale.

Another problem with digressing too far into the realms of ultimate causation is that we risk losing touch with the experiential aspects of a disaster, which can reveal critical causes and consequences. The anthropologist Christos Lynteris has argued that historians of epidemics who insist upon focusing upon processual dynamics tend to neglect the phenomenological dimensions of a disease outbreak. ${ }^{12}$ This critique is equally valid for environmental historians of disaster, who are adept at exposing the deep origins of risk but tend to treat the immediate experience of a hazard as little more than rhetorical garnish-descriptive details that help to evoke the scale of a catastrophe but have little analytical value. Recent studies, including Rebecca Jones's discussion of the experience of drought in this special issue, have

9 Mark Elvin, The Retreat of the Elephants: An Environmental History of China (New Haven, CT: Yale University Press, 2004); David Christian, Maps of Time: An Introduction to Big History (Berkeley, CA: University of California Press, 2004); Scott, Against the Grain.

10 Michael J. Watts and Hans G. Bohle, 'The Space of Vulnerability: The Causal Structure of Hunger and Famine', Progress in Human Geography 17, no. 1 (1993): 43-67, doi.org/10.1177/030913259301700103.

11 Memphis Minnie and Kansas Joe McCoy, 'When the Levee Breaks' (Charlie Patton, 1929).

12 Christos Lynteris, 'Introduction', The Cambridge Journal of Anthropology 32, no. 1 (2014): 24-31, doi.org/ 10.3167/ca.2014.320103. 
sought to overcome this temporal myopia. Of course, the experience of a disaster itself also unfolds on a variety of temporal scales. As Uwe Lübken and Christof Mauch have highlighted, disasters are often characterised by a slow build-up and, afterwards, their mental and physical impact can take years to erase. ${ }^{13}$

Differing hazard types create vastly differing temporal experiences, with each varying in the pace of its onset and in its duration. The historian Paul Cohen has observed that unlike floods, which occur at specific moments in time, droughts are essentially non-events. So much so, in fact, that the term drought serves as a metaphor, in sport and other fields, for a period of time in which an anticipated event is conspicuous by its absence. ${ }^{14}$ The agonising experience of waiting for the rains, which Rebecca Jones describes so evocatively in this special issue, was clearly quite different from the frantic scramble for safety experienced by those fleeing from urban fires described by Chris Courtney. Famine is, in some ways, a classic slow-onset disaster. Many of the worst subsistence crises have occurred following back-to-back harvest failures, which stretch hunger over the course of several years, as Cormac Ó Gráda has observed. ${ }^{15}$ Yet when multiple factors combine-such as state requisitioning, military conflict or price fluctuations - then 'blitz famines' of the kind that Mark Baker describes in this issue can occur. In 1940s Henan, famine built slowly before unleashing its consequences at terrifying speed, including rapid eruptions of violence and the swift sweep of a cholera outbreak.

In addition to onset and duration, the temporal experience of disaster is influenced by the frequency of recurrence. Greg Bankoff has argued that for some communities and cultures, disasters can be considered 'frequent life events', becoming integrated into the fabric of everyday life. ${ }^{16}$ Andrea Janku, Gerrit J. Schenk and Franz Mauelshagen have observed that while historians have preferred to focus on highmagnitude events, such as legendary earthquakes or eruptions, or on countries that experience annual extremes of weather such as typhoons, frequently recurring small-scale disasters have shaped human societies in subtle ways. ${ }^{17}$ In his study of risk perception and flood management in Renaissance Germany and Italy, Schenk argues that everyday hazards became embedded in the cultural and political makeup of these communities, and can, therefore, serve as a frame for understanding

13 Uwe Lübken and Christof Mauch, 'Uncertain Environments: Natural Hazards, Risk and Insurance in Historical Perspective', Environment and History 17 (2011): 1-2, doi.org/10.3197/096734011X12922358301012.

14 Paul A. Cohen, History in Three Keys: The Boxers as Event, Experience, and Myth (New York: Columbia University Press, 1997), 71-2.

15 Cormac Ó Gráda, Famine: A Short History (Princeton, NJ: Princeton University Press, 2009).

16 Greg Bankoff, Cultures of Disaster: Society and Natural Hazard in the Philippines (London: RoutledgeCurzon, 2003), 179-83, doi.org/10.4324/9780203221891.

17 Andrea Janku, Gerrit J. Schenk and Franz Mauelshagen, 'Introduction', in Historical Disasters in Context: Science, Religion, and Politics, ed. Andrea Janku, Gerrit J. Schenk and Franz Mauelshagen (New York and London: Routledge, 2012), 2-3. 
institutional and social learning. ${ }^{18}$ The once in a decade or century events that make headline news should not be ignored, yet daily lived hazards also have a longterm impact on nations and cultures. Recognising this, Eric Hsu has called for a new typology of disaster, one that distinguishes between those that are 'temporally focused' and those that are 'diffuse or recurrent'. ${ }^{19}$ This, arguably, better enables us to conceptualise disasters relating to long-term phenomena such as climate change.

The articles in this special issue explore the contrasting temporality of disasters in environmental history across time and space. Focusing on drought, famine, flood, fire and typhoons, they consider the vastly different ways that fast and slow hazards have affected societies and communities over time, from macro-scale political and economic factors, such as levels of social inequality and political marginalisation, to micro-level personal impacts on emotions, families and community cultures. They vary in temporal scope from roughly the 1700 s to the 1950 s, and range geographically from China, Australia and Malaysia to the Philippines-all the disasters under consideration presuppose a human-nature interaction, created or exacerbated through poor governmental management, unequal sociopolitical structures and/or the indiscriminate degradation of the immediate urban or agricultural environment. ${ }^{20}$

Rebecca Jones highlights the quotidian experience of a disaster, examining life for ordinary Australians during a period of exceptional climate variability. From the 1890 s to the 1940 s, there were five severe droughts that, she observes, have commonly been thought to have contributed to the forging of a national identity founded on 'stoicism in the face of hardship'. Jones goes further than this, however, to argue that the droughts had a far deeper reach into Australia's core cultural identity. Building on the recent emotional turn of social history, she shows how disasters did not simply arouse emotions but that emotions were at the heart of people's disaster responsiveness and adaption. Concomitantly, she investigates droughts not as single events but as an intermittent milieu of incremental and waning severity that provoked an atmosphere of continued uncertainty and anxiety. The hazards of which Jones writes were not exceptional or extraordinary events. Declining and increasing in scale, impact and intensity over five decades, they came instead to represent a way of living, and of coping, over generations.

18 Gerrit J. Schenk, 'Managing Natural Hazards: Environment, Society, and Politics in Tuscany and the Upper Rhine Valley in the Renaissance (ca. 1270-1570)', in Historical Disasters in Context, ed. Janku, Schenck and Mauelshagen, 31, 44.

19 Eric Hsu, 'Must Disasters Be Rapidly Occurring? The Case for an Expanded Temporal Typology of Disasters', Time and Society (published online 19 May 2017): 1-18, doi.org/10.1177/0961463X17701956.

20 Anthony Oliver-Smith, 'Theorising Disasters: Nature, Power and Culture', in Catastrophe \& Culture: The Anthropology of Disaster, ed. Susanna M. Hoffman and Anthony Oliver-Smith (Santa Fe, NM: School of American Research Press, 2002). 
James Warren adopts an even longer timescale, examining how the periodic famines that have struck the Philippines over the course of four centuries have been incubated by deep patterns of economic, political and meteorological history. The Spanish colonial government set this long-term trajectory in motion, as it diminished the entitlements of communities by preventing them from exploiting diverse natural resources and instead compelled them to engage in a form of export-driven monocrop agriculture. The means of subsistence of ordinary Filipino farmers was sacrificed to serve the demands of a globalising commodity market. This resulted in the slow-motion disaster of chronic hunger, which left the population acutely vulnerable to complete subsistence collapse, particularly in the wake of the highly destructive typhoons that regularly batter the archipelago. The poverty that many rural communities still suffer to this day in the Philippines has, therefore, been centuries in the making.

In British Malaya, Fiona Williamson argues, a less dramatic but no less significant process of land use change and social marginalisation was taking place over the nineteenth and early twentieth centuries. The change from small-scale shifting cultivation to intensive commercial agriculture led to the loss of virgin forests and traditional forms of subsistence living, as well as soil erosion. This last, in turn, was thought by contemporaries to have exacerbated river siltation, increased the intensity and frequency of flooding, and depleted soil productivity. In all cases, it was the poorer, least resilient smallholders who were the worst affected. Essentially, in both cases, fundamental socioeconomic inequalities meant that climatic and environmental extremes were the tipping point, not the source, of disaster.

Williamson's essay also highlights the multi-scalar nature of disaster. In British Malaya, erosion was a slow burner. On one level, erosion led to declining agricultural productivity, affecting the poorest farmers with the least ability to counteract the effect of poor soil with expensive fertilisers, or to mitigate damage by investing in preventative measures, such as terracing. On a different scale, eroded hill slopes could collapse suddenly after heavy rains, causing destruction of property and loss of human life. Ongoing throughout was the potential for soil wash to cause greater river siltation, potentially exacerbating the likelihood and intensity of floods during rainy seasons, according to the contemporary understanding. In this sense then, soil erosion could be considered as either a slow or fast disaster, depending upon the context. Likewise, Jones and Warren explore how drought or food scarcity formed a permanent thread through people's lives, the effects of which would wax and wane on different temporal and geographic scales. Both authors link the peak moments of the respective ongoing hazards to particular circumstances, either political or climatic, or both.

Though urban fire is a very different form of disaster, it shares a similar pattern of multi-temporal causality. Until recently, conflagrations were one of the most pervasive hazards of city life, turning landscapes of timber and thatch into smoke 
and ash at terrifying speed. Yet fires that burn out in a matter of hours are laid over much longer periods, as neighbourhoods are assembled from flammable materials, growing denser over the space of years or even decades. Conflagrations are also a product of their particular epochs - every age has its own style of burning. Previous histories have depicted the Chinese city of Hankou as desperately fire-prone due to a failure to modernise its architecture and urban planning. Chris Courtney argues that, while flammable buildings and overcrowding remained key issues, the nature of fire changed in the late nineteenth century as Hankou was flooded with a range of highly flammable foreign products. The chief culprit was kerosene, a hugely profitable fuel that revolutionised illumination but one that also caused terrible conflagrations. Courtney describes how the subsequent disasters, far from being evidence of the city's inability to advance into the modern world, were, in fact, by-products of its specific trajectory into material modernity. Though the story he tells is unique to Hankou, many key features were shared by other cities that lost control of their markets and governance during an era of formal and informal colonialism.

In contrast to fire, which is popularly understood to be amongst the most rapid forms of disaster, famine has usually been depicted as a painfully slow catastrophe. Mark Baker complicates this picture by highlighting the multiple temporal dimensions within which subsistence crises unfold. The problems affecting the north-central Chinese province of Henan in the 1940s had, in some respects, been created over the course of centuries, or even millennia. At the same time, they formed part of a multi-decade crisis—a slough as Brook might put it—which was punctuated by several of the worst famines in history. The particular crisis that struck the province in 1942-43 was caused by a range of factors, including war, excessive price increases, grain requisitioning and erratic rainfall, which had affected the province over a number of years. Although the famine seemed, therefore, to conform to the classic image of a slow-onset disaster, Baker demonstrates how it was punctuated by highly eventful periods, during which the causes and consequences of catastrophe sped up dramatically. The temporality of the famine could stretch out-with rural communities watching the cloudless skies for months on end-but could also compress - with rapidly escalating violence or pathogenic infections. Baker concludes by considering the deeper question of famine temporality in Chinese history, arguing that the crises that affected Henan in the 1940s and 1950s revealed the 'desynchronisation of time', caused by an agrarian economy being sacrificed for the 'short-term exigencies' of a modern state. 
This text is taken from International Review of Environmental History, Volume 4, Issue 2, 2018, edited by James Beattie, published 2018 by ANU Press, The Australian National University, Canberra, Australia.

doi.org/10.22459/IREH.04.02.2018.02 